\title{
Re-Print-Anaphylaxis Induced by Beer
}

\author{
Navarro L ${ }^{1 *}$, Lazo $C^{1}$, Pineda $P^{2}$, Labrador-Horrillo $\mathbf{M}^{3}$, Roger $\mathbf{A}^{1}$, Basagaña $\mathbf{M}^{1}$ \\ ${ }^{1}$ Allergy Section, Hospital Universitari Germans Trias i Pujol, Universitat Autónoma de Barcelona, Badalona, Spain \\ ${ }^{2}$ Application Lab, Diater, Madrid, Spain \\ ${ }^{3}$ Allergy Section, Department of Internal Medicine, Hospital Universitari de la Vall d'Hebron, Universitat Autónoma de Barcelona, Barcelona, Spain
}

*Corresponding Author: Lara Navarro Vives, Allergy Section, Hospital Universitari Germans Trias i Pujol, Universitat Autónoma de Barcelona, Badalona, Spain.

Received Date: October 27, 2021; Accepted Date: December 25, 2021; Published Date: January 04, 2022

Citation: Navarro L, Lazo C, Pineda P, Labrador-Horrillo M, Roger A, Basagaña M. (2022) Anaphylaxis Induced by Beer, J. Immunology and Inflammation Diseases Therapy. 5(1); DOI:10.31579/2637-8876/019

Copyright: (C) 2022 Lara Navarro Vives. This is an open-access article distributed under the terms of The Creative Commons Attribution License, which permits unrestricted use, distribution, and reproduction in any medium, provided the original author and source are credited.

\begin{abstract}
The prevalence of cereal allergy is highly influenced by geographical area and consumption habits. According to data from Alergologica 2015 [1], cereal allergy accounts for $2.1 \%$ of all cases of food allergy in Spain.

Beer is a barley-based alcoholic beverage that also contains hops, yeast, and other cereals (wheat, oats, corn, and even rye). Barley is also the basis of malt vinegar, whiskey, and gin. Several allergens of barley have been described, including lipid transfer protein (LTP), - and ß-amylase, gliadin, glutenin, peroxiredoxin, thionin, and trypsin inhibitor [2].

Key words: beer allergy; barley allergy; component-resolved diagnosis; food allergy; anaphylaxis; palabras clave: alergia a cerveza. alergia a la cebada. diagnóstico por componentes. alergia a alimentos. anafilaxia
\end{abstract}

The prevalence of cereal allergy is highly influenced by geographical area and consumption habits. According to data from Alergologica 2015 [1], cereal allergy accounts for $2.1 \%$ of all cases of food allergy in Spain.

Beer is a barley-based alcoholic beverage that also contains hops, yeast, and other cereals (wheat, oats, corn, and even rye). Barley is also the basis of malt vinegar, whiskey, and gin. Several allergens of barley have been described, including lipid transfer protein (LTP), $\alpha$ - and $\beta$-amylase, gliadin, glutenin, peroxiredoxin, thionin, and trypsin inhibitor [2].

We present a case of beer-induced anaphylaxis. A 48-year-old man with no personal history of allergy experienced sudden loss of consciousness after drinking beer.

Five to six years previously, he had experienced pharyngeal pruritus and mild dyspnea with no other systemic symptoms after drinking beer, which he subsequently avoided for several years. After trying it again, he immediately lost consciousness and experienced a mandibular fracture. The physical examination at the time of the consultation was normal. All ingredients except barley were tolerated afterwards.

Skin prick testing (SPT) with a standard panel of aeroallergen extracts was positive only to mugwort. The results of SPT with food extracts were negative. SPT with commercial cereal extracts (corn, wheat, rice, oat, barley, rye, gluten, and gliadin [LETI]) was negative, with a mild response to barley (histamine, $<2 \times 2$ ) to barley. Prick by prick testing with beer (San Miguel) was positive $(5 \times 7 \mathrm{~mm})$. Total $\mathrm{IgE}$ and basal tryptase values (ImmunoCAP, Thermo Fisher Scientific) were $160 \mathrm{kU} / \mathrm{L}$ and $3.84 \mu \mathrm{g} / \mathrm{L}$ respectively, and specific IgE antibodies were as follows: wheat (Triticum aestivum), $0.03 \mathrm{kUA} / \mathrm{L}$; barley (Avena sativa), $<0.1$ kUA/L; hop (Humulus lupus), <0.1 kUA/L; rPru p 3, <0.1 kUA/L; and $\omega$ 5 gliadin, $0 \mathrm{kUA} / \mathrm{L}$. ImmunoCAP ISAC microarray (Thermo Fisher Scientific) revealed a positive result only for nArt v 1 ( 0.6 ISU).

Protein extract from hop, rice, barley, rye, corn, wheat, and beer yeast were homogenized in phosphate-buffered saline, dialyzed, concentrated, and stabilized by lyophilization. Sodium dodecyl sulphatepolyacrylamide gel electrophoresis (SDS-PAGE) was carried out under reducing conditions as described by Laemmli [3] with 7 different beer brands, hop, rice, barley, rye, corn, wheat, and beer yeast extracts in patient sera. Western blot revealed an IgE-binding band of 10-12 $\mathrm{kDa}$ in the extract of all the beers (independently of the gluten content) and barley (Figure), which was extracted from the gel, digested with trypsin, and analyzed using mass spectrometry (HR, ORBITRAP, short gradient), as previously described [4]. Three peptides from LTP1 (Hor v 7k-LTP) with $15 \%$ of coverage were identified. 

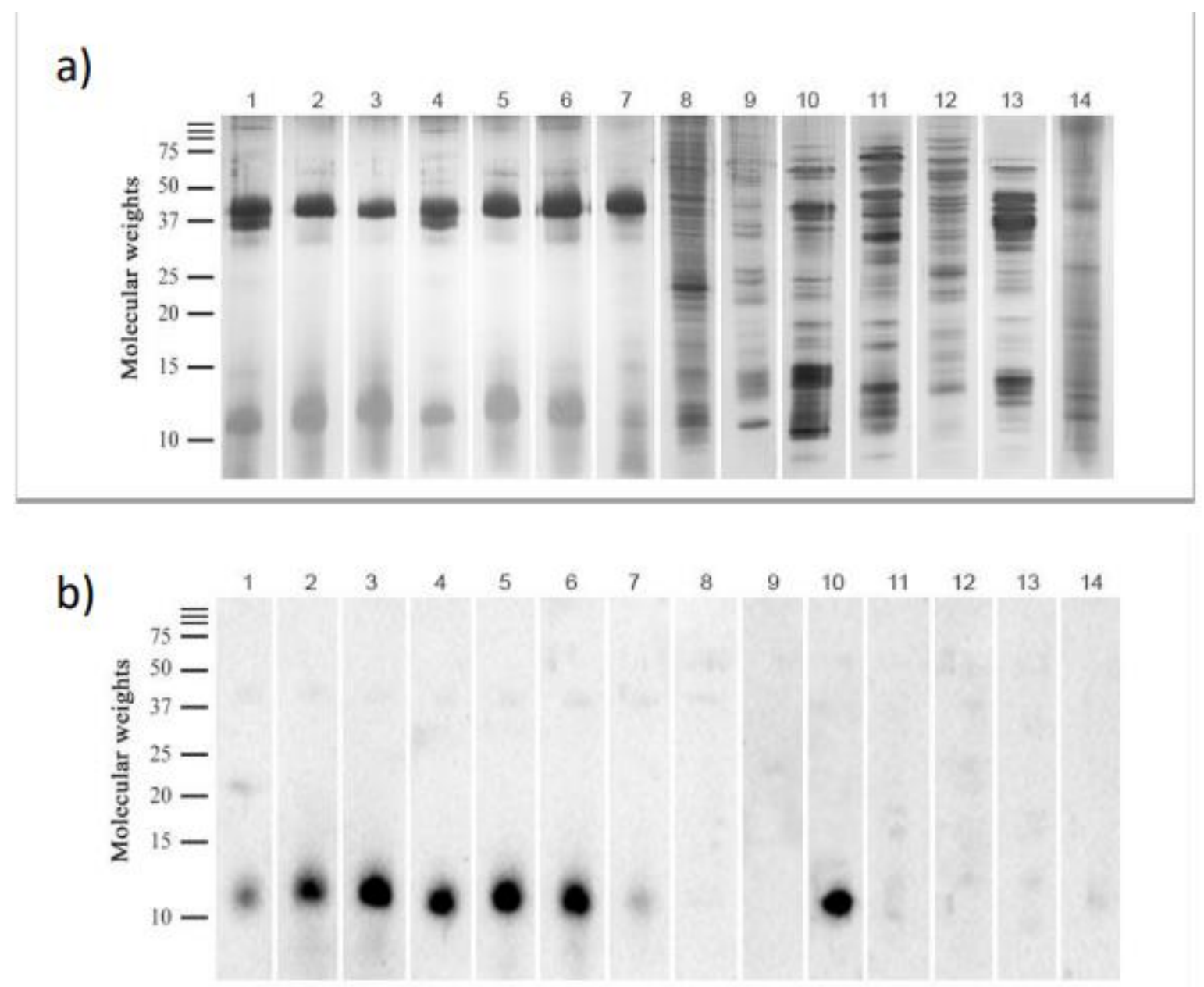

Figure A: SDS-PAGE. B, Western blot. Lane 1, San Miguel gluten-free beer; lane 2, San Miguel beer; lane 3, San Miguel alcohol-free beer; lane 4,
Mahou gluten-free beer; lane 5, Mahou beer; lane 6, Mahou double-hop beer; Lane 7, Dutch beer (Carrefour); lane 8, hop; lane 9, rice; lane 10,
barley; lane 11, rye; lane 12, corn; lane 13, wheat; lane 14, beer yeast.

LTP1 results from a modification of posttranslational LTP by a different type of bond between aspic acid and ester linkages. Low amounts of LTP1 are present in barley kernel. LTP1 is highly stable during malting and brewing and is unaffected by boiling and proteolysis; therefore, it can be found intact in beer, where it is a major protein component [5].

Reactivity of IgE to Hor v 7k-LTP is often associated with severe systemic symptoms, although unlike Hor v 14, which is a classic LTP of barley and LTP1 type, it does not cross-react with other LTPs [5].

Several studies identified a $10-\mathrm{kDa}$ allergenic protein by Western blot in beer-allergic patients, suggesting that the culprit allergen could be the classic LTP of barley (Hor v 14) [6-10]. In most case reports, patients did not tolerate other fruits and nuts, thus suggesting cross-reactivity with other LTPs [6-8].

Tolerance of other foods, negative skin prick test results to foods, and negative serum specific IgE results for other LTPs point to Hor v 7k-LTP as the causative allergen in this case.

In conclusion, our study of a case of anaphylaxis after ingestion of beer revealed the possible culprit allergen to be the LTP Hor v 7k. To date, this is the first report of an LTP1 of barley as the causative allergen of beer allergy. Our findings have implications for dietary recommendations to this patient, namely, that he should avoid barley and manufactured products that contain barley.

\section{References}

1- Ojeda P, Ibáñez MD, Olaguibel JM, Sastre J, Chivato T; investigators participating in the National Survey of the Spanish Society of Allergology and Clinical Immunology Alergológica 2015. Alergológica 2015: A National Survey on Allergic Diseases in the Spanish Pediatric Population. J Investig Allergol Clin Immunol. 2018;28(5):321-329.

2- www.allergome.org.

3- Laemmli UK. Cleavage of structural proteins during assembly of the head of bacteriophage T4. Nature 1970;277:680-685.

4- Pastor C, Cuesta-Herranz J, Cases B, Pérez-Gordo M, Figueredo $\mathrm{E}$, De Las Heras, et al. Identification of major allergens in watermelon. Int Arch Allergy and Immunol. 2009;149(4):291298.

5- Curioni A, Santucci B, Cristaudo A, Canistraci C, Pietravalle M, Simonato B, et al. Urticaria from beer: An immediate 
hypersensitivity reaction due to a $10-\mathrm{kDa}$ protein derived from barley. Clin Exp Allergy. 1999;29(3):407-413.

6- Nusem D, Panasoff J. Beer anaphylaxis. Isr Med Assoc J. 2009;11(6):380-1.

7- Asero R, Mistrello G, Roncarolo D, Amato S, VanRee R. A case of allergy to beer showing crossreactivity between lipid transfer proteins. Ann Allergy Asthma Immunol. 2001;87(1):65-67.
8- Herzinger T, Kick G, Ludolph-Hauser D, Przybilla B. Anaphylaxis to wheat beer. Ann Allergy Asthma Immunol. 2004;92(6):673-675.

9- Bansal RA, Tadros S, Bansal AS. Beer, Cider, and Wine Allergy. Case Reports Immunol. 2017:1-4.

10- Song Z, Chen W, Huang X, Zhou X, Luo J, Wang H, et al. Sensitization to beer ingredients in Chinese individuals with beer allergy: A clinical study of 20 cases. Int Arch Allergy and Immunol. 2014;163(2):135-141.
This work is licensed under Creative Commons Attribution 4.0 License

To Submit Your Article Click Here: Submit Manuscript

DOI: $10.31579 / 2637-8876 / 019$
Ready to submit your research? Choose Auctores and benefit from:

* fast, convenient online submission

* rigorous peer review by experienced research in your field

* rapid publication on acceptance

* authors retain copyrights

* unique DOI for all articles

* immediate, unrestricted online access

At Auctores, research is always in progress.

Learn for more auctoresonline.org/journals/immunology-andinflammation-diseases-therapy- 